\title{
Changes in morphology and diet of the coral Stylophora pistillata along a depth gradient
}

\author{
Shai Einbinder ${ }^{1,2,3, *, * *}$, Tali Mass ${ }^{1,3, *}$, Eran Brokovich ${ }^{1,2,3}$, Zvy Dubinsky $^{4}$, \\ Jonathan Erez ${ }^{1,5}$, Dan Tchernov ${ }^{1,3}$ \\ ${ }^{1}$ The Interuniversity Institute for Marine Sciences at Eilat, PO Box 469, Eilat 88103, Israel \\ ${ }^{2}$ Marine Twilight-Zone Research \& Exploration (MTRX), The Interuniversity Institute for Marine Sciences at Eilat (IUI), \\ PO Box 469, Eilat 88103, Israel \\ ${ }^{3}$ Evolution Systematics and Ecology Department, Life Sciences Institute, The Hebrew University of Jerusalem, \\ Jerusalem 91904, Israel \\ ${ }^{4}$ The Mina \& Everard Goodman Faculty of Life Sciences, Bar-Ilan University, Ramat-Gan 52900, Israel \\ ${ }^{5}$ Institute of Earth Sciences, The Hebrew University of Jerusalem, Jerusalem, Israel
}

\begin{abstract}
The light-limited environment of tropical coral reefs has not been intensively studied due to technical limitations. Studying this vast part of the coral reef is paramount to understanding the ecological and physiological significance of coral-algae symbiosis and defining the boundaries imposed on its bathymetric distribution by the underwater light field. In the present study we describe morphological changes in colonies of the coral Stylophora pistillata and track changes in its carbon sources (autotrophic/heterotrophic behavior) along its full bathymetric distribution. The growth form of hermatypic corals must compromise between an optimal light-trapping surface facilitating photosynthesis and other structures and/or mechanisms that enhance exploitation of nutrientrich sources such as zooplankton. That architectural modulation is constrained within the speciesspecific structural and biological characteristics. We found that the profusely branched $S$. pistillata colonies shift between subspherical morphology at high-light environments to a planar structure at depth. The stable carbon isotopic composition $\left(\delta^{13} \mathrm{C}\right)$ of the host coral tissue changed from a value of $-15 \%$ in shallow water to $-23 \%$ at the deep reef. The latter value indicates either a carbon source with a stable isotope composition equal or below $-23 \%$ or, alternatively, internal carbon cycling between host and algae that involves isotopic fractionation $(\varepsilon)$. The $\delta^{13} \mathrm{C}$ values showed significant correlation to morphological traits, but contradicting trends were found within the traits. A clear shift to heterotrophy was not apparent, which, therefore, suggests that the internal cycling and Rubisco activity are the dominant processes determining isotopic composition.
\end{abstract}

KEY WORDS: Corals $\cdot$ Zooxanthellae $\cdot \delta^{13} \mathrm{C} \cdot$ Deep coral reef $\cdot$ Light $\cdot$ Calcification $\cdot$ Skeleton Resale or republication not permitted without written consent of the publisher

\section{INTRODUCTION}

Hermatypic (reef-building) corals harbor dinoflagellate endosymbionts, mostly of the genus Symbiodinium, also known as zooxanthellae (Brandt 1883). In many cases, they supply a major portion of the coral's energy demands. Additionally, the presence of zooxanthellae enhances the propagation of corals through the light-enhanced calcification phenomenon (Goreau
\& Goreau 1959, Muscatine et al. 2005, Schneider \& Erez 2006). Although it is generally accepted that photoautotrophic processes provide the primary source of fixed carbon for corals, the relative contribution of heterotrophy to the diet of stony corals remains poorly understood (Palardy et al. 2005).

The relative contribution of each carbon source can be deduced from the stable isotope composition of carbon, provided that these alternative sources have dis- 
tinct $\delta^{13} \mathrm{C}$ signatures (Deniro \& Epstein 1978). In the special case of corals, the 2 partners that make up the holobiont interact at the basic metabolic level that includes reciprocal fluxes of energy and nutrient-rich compounds (Muscatine et al. 2005). Evidence supporting the autotrophic nature of zooxanthellate corals is found in shallow-water corals, where the $\delta^{13} \mathrm{C}$ of both the coral host and the symbiont algae are similar. Muscatine et al. (1989) reported that as depth increased, so did the difference between zooxanthellae and coral tissue $\delta^{13} \mathrm{C}$, and the latter approached that of oceanic particulate organic carbon. This suggests that carbon is translocated at all depths and deep-water corals draw significantly on allochthonous sources of carbon. In addition, the $\delta^{13} \mathrm{C}$ of the coral tissue is significantly more positive (contains more ${ }^{13} \mathrm{C},-10$ to $-14 \%$ ) than that of the zooplankton (ca. $-20 \%$ ), a primary food source (Muscatine et al. 2005, Swart et al. 2005). This indicates that, for those corals studied, the supply of carbon to the coral tissue in shallow water takes place predominantly through photosynthetic products of the zooxanthellae and, to a lesser extent, through predation (Grottoli et al. 2006). The high-light driven influx of ${ }^{13} \mathrm{C}$-rich carbon (relative to other sources such as zooplankton or particulate organic matter [POM]) through the symbiotic algae to the coral host results in the maintenance of similar isotopic composition of the coral tissue and its photosymbionts. With increasing depth, the $\delta^{13} \mathrm{C}$ of coral tissues becomes more negative $\left({ }^{12} \mathrm{C}\right.$-rich) and approaches that of the zooplankton, a shift indicating a transition from autotrophy to heterotrophy (Swart et al. 2005). The case is even more complicated as revealed in a recent study by Bachar et al. (2007), who have shown that autotrophically derived carbon compounds are quickly consumed by respiration, while predation-derived carbon is incorporated throughout the coral tissue and remains there for a much longer time.

Some coral taxa are restricted to narrow depths while others occur over a broad bathymetric range (Maier et al. 2003). Depth-related changes in light regimes have physiological consequences and often result in significant morphological adjustments that maximize light capture (Bruno \& Edmunds 1997, Muko et al. 2000, Vermeij \& Bak 2003). Porter (1976) hypothesized that more autotrophic corals, those with branching skeletons, small polyps and high surface to volume ratios, photoacclimate better to low light than corals with massive skeletons, large polyps and low surface to volume ratios which are presumably more heterotrophic. Furthermore, Sebens et al. (1998) pointed out that Madracis mirabilis, a branching coral with small polyps and a high surface to volume ratio, captured far more prey per unit coral biomass than Montastrea cavernosa, a massive coral with large polyps and a low surface to volume ratio. Anthony \& Fabricius (2000) suggested that distribution and size of corallites may optimize the ratios of phototrophic to heterotrophic nutrition: small and tightly packed corallites would increase the amount of surface area available for zooxanthellae, thereby maximizing photosynthetic potential. Crabbe \& Smith (2002) and Crabbe et al. (2004) showed that in colonies subjected to lower ambient light intensities, polyps may meet a greater proportion of their energy requirements by heterotrophy and, therefore, the corallites may need a better-developed food-capturing mechanism (i.e. a larger number and length of tentacles) proportional to increased corallite dimensions. Based on isotopic data, Grottoli \& Wellington (1999) showed that mounding species from shallow sites showed no difference in reliance upon heterotrophic input between congeners of differing polyp sizes. In addition, Palardy et al. (2005) showed that feeding rates increased with depth and were higher in coral species with mounding morphology than in those with branching morphology. They have also shown that feeding did not differ with polyp size within morphology, and suggested that coral feeding rates are facultative, may vary due to increased feeding effort and are not necessarily related to colony morphology.

The hermatypic coral Stylophora pistillata (Esper, 1797) has a wide bathymetric range in the Gulf of Aqaba. This species is distributed from the shallow waters of the reef flat $(1 \mathrm{~m})$ and the lagoon $(1$ to $3 \mathrm{~m})$ to depths of $70 \mathrm{~m}$ (Mass et al. 2007). Colony color varies from ivory in the shallow reef to dark brown (upper side) in the deep reef (Mass et al. 2007). Mass et al. (2007) showed an adjustment in harvesting and utilization of light by the algal symbionts depending on the light environment. At all light intensities but the lowest, there was a consistent ratio of calcification to photosynthesis. In the deepest $S$. pistillata colonies examined (65 m), there was no evidence of light-enhanced calcification, and Mass et al. (2007) suggested that such colonies are likely to subsist mainly on zooplankton predation. Thus, they concluded that $S$. pistillata colonies from the deepest sites are only marginally supported by the translocation of photosynthetic products due to the light-limited production rate of the symbiotic algae. Hence, we expected a large difference in $\delta^{13} \mathrm{C}$ values between zooxanthellae and coral tissue with increasing depth, which would correlate with shifting photosynthesis to predation ratios with the decreasing light, concomitant with changes in colony morphology.

Our aims were to follow the major carbon source shifts in coral metabolism at various depths and to study the coral's morphological adaptation to utilizing these sources. We examined the variation in $\delta^{13} \mathrm{C}$ of coral tissue and zooxanthellae in the coral Stylophora pistillata along a depth gradient of 0 to $65 \mathrm{~m}$. We also 
measured changes in the morphology of the entire colony, including branch thickness, and polyp size and density along the depth gradient.

\section{MATERIALS AND METHODS}

Samples of Stylophora pistillata were collected under a special permit by the Israeli Natural Parks Authority in front of the Interuniversity Institute of Marine Sciences, Eilat, Gulf of Aqaba, Red Sea $\left(29^{\circ} 30^{\prime} \mathrm{N}, 34^{\circ} 56^{\prime} \mathrm{E}\right)$, from depths of 5, 10, 30, 50 and $65 \mathrm{~m}$. Deep dives were accomplished using Megalodon closed circuit rebreathers (Innerspace Systems). Plankton was sampled by manually towing plankton nets $(0.5 \times 2 \mathrm{~m}$, mesh size $=100 \mu \mathrm{m})$ for $10 \mathrm{~min}$ at 3 and $60 \mathrm{~m}$ $(\mathrm{n}=3)$. Three branches from each of 3 different colonies were collected at each depth in summer (July) and winter (February) 2004 (Mass et al. 2007). The photobiology of these branch samples has been described by Mass et al. (2007). All coral samples were measured for morphological parameters and isotopic composition of host and zooxanthellae.

Isotopic analysis. Immediately after collection, corals were transferred to the laboratory; within $15 \mathrm{~min}$ the tissue was removed with an airbrush connected to a reservoir of filtered seawater $(0.20 \mu \mathrm{m}$ filter $)$. The resulting homogenate was centrifuged for $4 \mathrm{~min}$ at $1323 \times g$, followed by a second centrifugation of the supernatant for $10 \mathrm{~min}$ at $2068 \times g$. The supernatant (coral tissue homogenate) was acidified with $1 \mathrm{~N} \mathrm{HCl}$ to remove dissolved inorganic carbon (DIC). The pellet of the first centrifugation (consisting mostly of zooxanthellae) was washed with filtered seawater, resuspended in $1 \mathrm{ml}$ filtered seawater and then re-centrifuged for $4 \mathrm{~min}$ at $2687 \times g$. Plankton samples were vacuum-filtered onto Whatman GF/F filters and dried at $60^{\circ} \mathrm{C}$, while zooplankton and coral samples were lyophilized for $24 \mathrm{~h}$ and sent for isotopic analysis.

The isotopic ratios of carbon and nitrogen in symbiont and host samples were measured by a continuous flow-isotope ratio mass spectrometry (CF-IRMS) system: a FlashEA 1112 elemental analyzer connected to a DeltaPlus XL mass spectrometer (Thermo Scientific). The reported $\delta$-values were calculated by Eq. (1), where $R$ is the ratio between heavy and light isotopes, and is expressed versus the Pee Dee Belemnite (PDB) standard for carbon. Mass spectrometer precision $(1 \sigma)$ for $\delta^{13} \mathrm{C}$ was $0.15 \%$.

$$
\delta^{13} \mathrm{C}=\left(\frac{R_{\text {sample }}}{R_{\text {standard }}}-1\right) \times 1000
$$

The $\delta^{13} \mathrm{C}$ presented are the mean values of separated zooxanthellae and coral fractions from each depth. The value of each sample was generated from 2 duplicates.
Morphological examination. All skeletons were bleached with $70 \%$ commercial cleaning bleach in order to remove the tissue, rinsed in distilled water and dried. The following branch and corallite traits were measured $(\mathrm{cm})$ using a Nikon dissecting scope equipped with a scale (reticule) built into one eyepiece: branch diameter (BD) was measured with calipers $2 \mathrm{~cm}$ below the end of the branch, and polyp density (PD) was reported as the average number of polyps from 3 arbitrary $1 \mathrm{~cm}^{2}$ squares taken at a distance of $2 \mathrm{~cm}$ from the terminal branch end. Three randomly selected corallites, $2 \mathrm{~cm}$ from the terminal branch end, were measured on each fragment collected. One measurement was made for corallite spacing (CS, minimum distance to the nearest neighbor) and a single measurement was made for corallite diameter (CD, maximum diameter across corallite) (Fig. 1). Colony morphology was determined in situ by measuring the height and diameter of 64 colonies of Stylophora pistillata along the depth gradient. The ratio of colony diameter to maximal height was used as an indicator of the surface area to volume ratio of the colony.

Data analysis. All data was tested for normality using the Kolmogorov-Smirnov test and for homogeneity of variance using Cochran's test. In cases in which homogeneity of variance was achieved, we used 1- and 2way ANOVAs and a multiple comparison test (Fisher's LSD). If homogeneity of variance or normality was not achieved, a non-parametric Kruskal-Wallis ANOVA was used $\left(p_{\text {crit }}=0.05\right)$. Correlations were run between all parameters. Mean values are presented \pm SD. STATISTICA 6.0 (StatSoft) software was used.

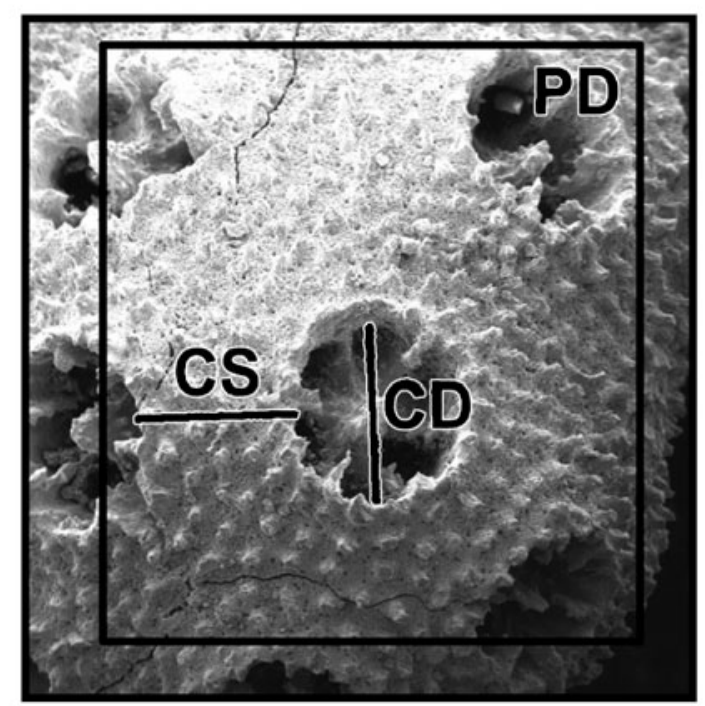

Fig. 1. Stylophora pistillata. Measures of polyp morphology. PD: polyp density, number of polyps in a selected area $\left(\mathrm{cm}^{-2}\right)$; $\mathrm{CD}$ : corallite diameter, maximum diameter across corallite; and CS: corallite spacing, minimum distance between selected corallite to nearest adjacent corallite 


\section{RESULTS}

\section{Stable isotopes}

The mean $\delta^{13} \mathrm{C}$ of coral tissue $(-19.0 \pm 1.4)$ was significantly more negative than that of zooxanthellae (-15.9 \pm 1.0 ; 2-way ANOVA, p < 0.05) (Fig. 2).

$\delta^{13} \mathrm{C}$ decreased with increasing depth both in the coral tissue and the zooxanthellae $\left(\mathrm{r}^{2}=0.95,0.87, \mathrm{n}=\right.$ 15 , respectively) (Table 1). Clear and significant differences were found between coral host and zooxanthellae samples at almost all depths (2-way ANOVA, p < 0.05). Fisher's LSD distinguished both zooxanthellae and coral tissue samples from shallower reefs (5 to $30 \mathrm{~m}$ ) from the deep reefs (50 to $65 \mathrm{~m})$ ( $\mathrm{p}<0.001)$.

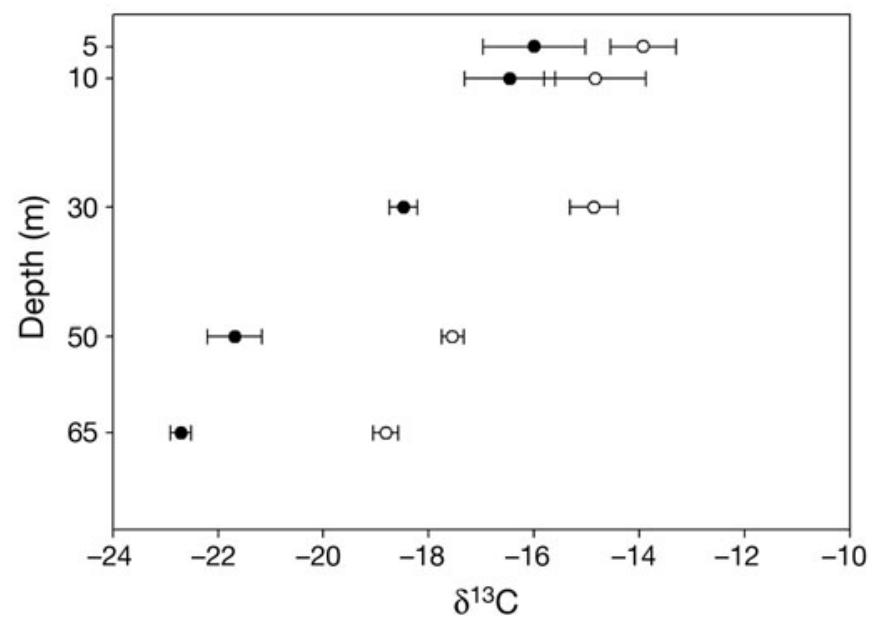

Fig. 2. Stylophora pistillata. Changes in $\delta^{13} \mathrm{C}$ of coral tissue (•) and zooxanthellae $(0)$ along the depth gradient. Error bars = $\mathrm{SD} ; \mathrm{n}=3$ at each depth

Table 1. Correlations between isotopic signatures of both Stylophora pistillata and zooxanthellae and depth as well as coral morphological parameters. ${ }^{*}$ Significant trends; zoox: zooxanthellae

\begin{tabular}{|lccc|}
\hline Variables & $\mathrm{r}^{2}$ & $\mathrm{p}$ & $\mathrm{n}$ \\
\hline$\delta^{13} \mathrm{C}$ coral/depth & 0.95 & $0.000^{*}$ & 15 \\
$\delta^{13} \mathrm{C}$ zoox/depth & 0.86 & $0.000^{*}$ & 15 \\
Branch diameter/depth & 0.71 & $0.000^{*}$ & 15 \\
Corallite diameter/depth & 0.77 & $0.000^{*}$ & 15 \\
Corallite spacing $/$ depth & 0.72 & $0.000^{*}$ & 15 \\
Corallite spacing $/ \delta^{13} \mathrm{C}$ coral & 0.65 & 0.000 & 15 \\
Branch diameter $/ \delta^{13} \mathrm{C}$ coral & 0.67 & $0.000^{*}$ & 15 \\
Corallite diameter $/ \delta^{13} \mathrm{C}$ coral & 0.80 & $0.000^{*}$ & 15 \\
Corallite spacing $/ \delta^{13} \mathrm{C}$ zoox & 0.32 & $0.027^{*}$ & 15 \\
Branch diameter $/ \delta^{13} \mathrm{C}$ zoox & 0.54 & $0.001^{*}$ & 15 \\
Corallite diameter $/ \delta^{13} \mathrm{C}$ zoox & 0.69 & 0.000 & 15 \\
& & & \\
\hline
\end{tabular}

\section{Morphology}

Morphological variation in colony shape, branch and corallite parameters was found among Stylophora pistillata colonies from different depths. Colonies changed from a hemispherical shape with thick branches (shallow reefs), to planar colonies with thinner branches (deep reefs). A positive exponential correlation between depth and the ratio of colony diameter to maximal height $\left(\mathrm{r}^{2}=0.79, \mathrm{n}=65\right)$ (Fig. 3) was found.

Branch diameter decreased from $7.23 \pm 0.24$ to $4.06 \pm$ $0.38 \mathrm{~mm}$ (Fig. 4) with increasing depth $\left(\mathrm{r}^{2}=0.71, \mathrm{n}=\right.$ 15) (Table 2). Fisher's LSD showed that colonies deeper than $30 \mathrm{~m}$ differed from the shallow colonies, while no differences were found between the deep corals (50 and $65 \mathrm{~m}$ ).

Corallite diameter decreased significantly with depth (Kruskal-Wallis ANOVA, $\mathrm{p}<0.05, \mathrm{n}=15$ ), while the distance between polyps increased significantly ( $p<0.05, n=15$ ) (Fig. 5). Fisher's LSD showed that the deeper colonies differed from the shallow ones both in corallite diameter and spacing, while no differences were found among shallow corals (5 to $30 \mathrm{~m})$.

Strong and significant correlations were found between the following parameters: (1) corallite diameter to $\delta^{13} \mathrm{C}$ of the coral $\left(\mathrm{r}^{2}=0.80, \mathrm{n}=15\right)$ and the zooxanthellae $\left(\mathrm{r}^{2}=0.69, \mathrm{n}=15\right) ;(2)$ branch diameter to $\delta^{13} \mathrm{C}$ of the coral $\left(\mathrm{r}^{2}=0.67, \mathrm{n}=15\right)$ and the zooxanthellae $\left(r^{2}=0.54, n=15\right)$; and (3) corallite spacing to $\delta^{13} \mathrm{C}$ of the coral $\left(r^{2}=0.65, n=15\right)$ and the zooxanthellae $\left(r^{2}=0.50\right.$, $\mathrm{n}=15$ ) (Table 1).

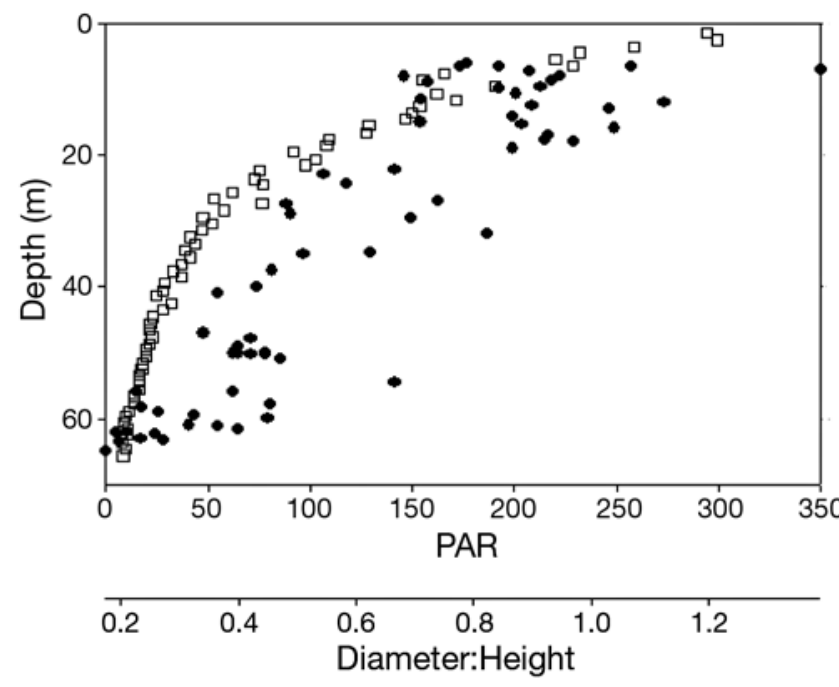

Fig. 3. Stylophora pistillata. Changes in the ratio of colony diameter to height $(\bullet)$ and photosynthetically active radiation PAR (口) along the depth gradient (error bars $=S D, n=65$ ) 


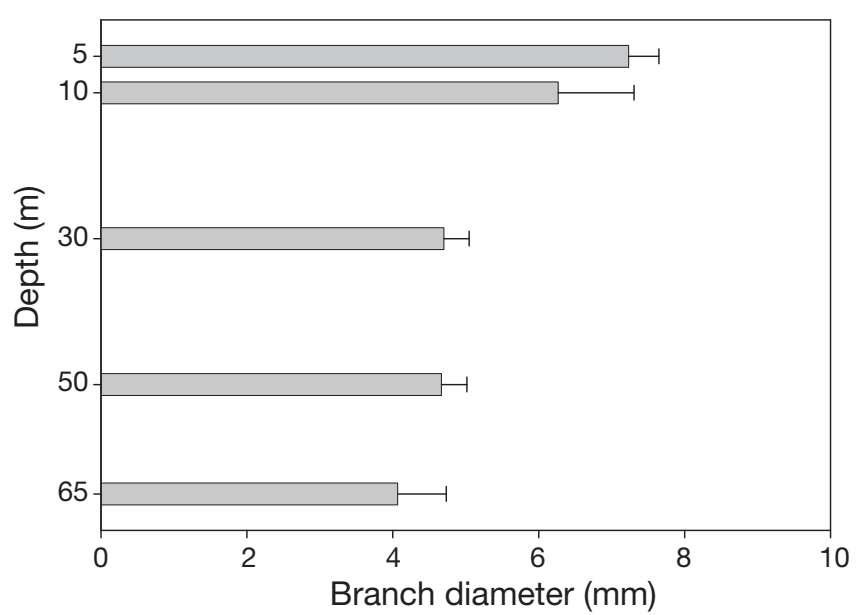

Fig. 4. Stylophora pistillata. Changes in branch diameter of sampled coral colonies $(\mathrm{mm})$ along the depth gradient (error bars $=\mathrm{SD}, \mathrm{n}=15$ )

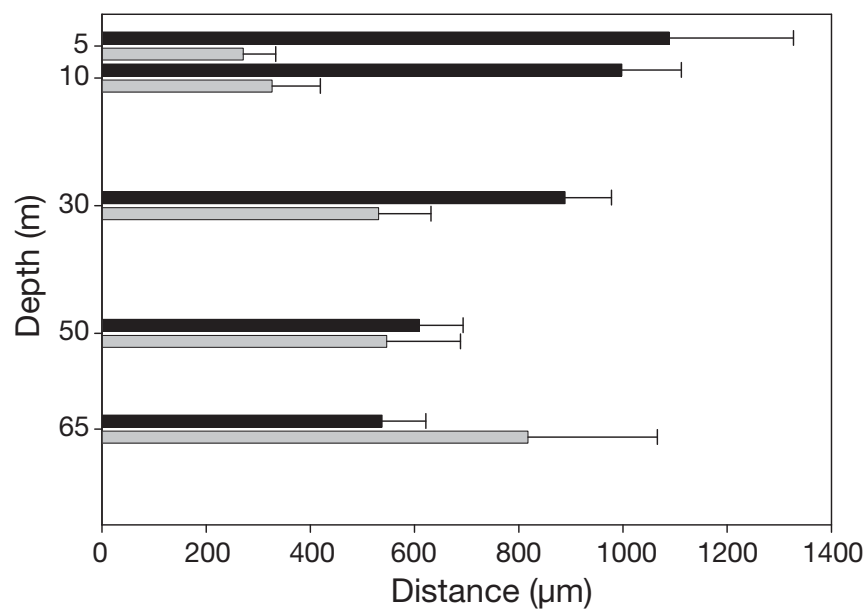

Fig. 5. Stylophora pistillata. Changes in corallite diameter (black) and corallite spacing (grey) along the depth gradient (error bars $=\mathrm{SD}, \mathrm{n}=15$ )

\section{DISCUSSION}

\section{Carbon}

The proportion of photosynthate translocated to the coral host relative to the amount of carbon supplied via predation will determine the overall isotopic composition of the coral tissue. Carbon content of both tissue and zooxanthellae of Stylophora pistillata became increasingly depleted of ${ }^{13} \mathrm{C}$ with increasing depth. At $65 \mathrm{~m}$, the tissue had an extremely light isotopic composition, as reported previously by Muscatine et al. (1989). A clear separation between zooxanthellae $\delta^{13} \mathrm{C}$ and host values appeared at all depths. This difference was greater at the deeper part of the reef, and might reflect the reduced dependence on zooxanthellae as the primary source of carbon. However, from the depth of $\geq 30 \mathrm{~m}$, this value remained constant, a fact which strengthens the hypothesis of a common dependence of symbiont and host on the same carbon source at depth. It is widely accepted that under high photosynthetic rates in the shallow reef, carbon isotope fractionation is attenuated as demand for carbon is much higher. Under such high-light conditions, Rubisco is forced to incorporate any available carbon, thereby reducing discrimination against the heavy isotopes common under lower supply/demand ratios (O'Leary 1988, Swart et al. 2005). However, in this case, there was no significant depletion in the heavy isotope of the algae over the top $30 \mathrm{~m}$. Moreover, there was a 5.3-fold drop in the photosynthetic rate of corals between 5 and $30 \mathrm{~m}$ in depth (from 0.0344 to $0.0065 \mu \mathrm{mol} \mathrm{O} \mathrm{Cm}^{-2} \mathrm{~h}^{-1}$, respectively). Hence, a $70 \%$ decrease in light intensity leading to a massive decline in photosynthesis did not affect the carbon isotope composition of the algae at these depths. In contrast, the coral tissue carbon isotopic composition was significantly depleted between 5 and $30 \mathrm{~m}$ in depth. This suggests that, with increasing depth, the coral tissue became more dependent on carbon from a heterotrophic source rather than photosynthesis. The symbiotic algae that are not carbonlimited even in the higher photosynthetic-rate range indicate the use of $\mathrm{HCO}_{3}{ }^{-}$as the primary substrate for photosynthesis. Further support for the latter suggestion is the relatively heavy isotopic composition $\left(-14 \%\right.$ ) from 0 to $30 \mathrm{~m}$, as $\mathrm{HCO}_{3}{ }^{-}$is 7 to $10 \%$ heavier than $\mathrm{CO}_{2}$ species (Deuser \& Degens 1967, Mook et al. 1974). At greater depths, the algae become less productive until near-zero values of net photosynthesis are reached (Mass et al. 2007). The increasingly lighter isotopic composition of the algae with depth (from 30 to $65 \mathrm{~m}$ ) cannot be explained by the carbon supply/ demand theory (O'Leary 1988, Swart et al. 2005), as there was no effect of photosynthetic rates on isotopic composition, as mentioned above. Metabolic $\mathrm{CO}_{2}$ can be utilized through photosynthesis and affect the isotopic composition of the algae; however, this is not likely because of the extremely poor photosynthetic rates at these depths and the abundance of $\mathrm{HCO}_{3}{ }^{-}$. Moreover, the deeper the coral, the slower the photosynthetic rate, and less carbon is incorporated as acid stable products. Under such conditions, the only other carbon source available to the zooxanthellae originates in the coral tissue. Since photosynthesis at these depths is minor and the primary source of carbon for photosynthesis is $\mathrm{HCO}_{3}^{-}$(Al-Moghrabi et al. 1996, Goiran et al. 1996, Furla et al. 2000), carbon sources such as amino acids or carbohydrates translocated from the coral to the algal symbionts becomes a realistic possibility. At the deeper part of the reef, $\delta^{13} \mathrm{C}$ of 
both tissue and zooxanthellae reached the most negative values: the tissue of colonies collected at $65 \mathrm{~m}$ reached a strikingly negative $\delta^{13} \mathrm{C}$ value of -22.7 . This isotopic value cannot be solely explained by a more heterotrophic diet, as $\delta^{13} \mathrm{C}$ values of zooplankton ranged from -19.6 to $-20.89 \%$. A diet composed even of a $100 \%$ reliance on predation cannot explain the observed tissue composition. We assume that, comparing the same relative portion of coral tissues, the carbohydrates are translocated from the zooxanthellae, hence contributing relatively light carbon to the mass balance as $\delta^{13} \mathrm{C}$ of zooxanthellae at $65 \mathrm{~m}$ measures $-19 \%$. We therefore suggest, based on both carbon and nitrogen isotope data, that coral tissue supplies zooxanthellae with carbon-rich metabolites as well as nitrogen-rich compounds (Falkowski et al. 1993). The latter are recycled back to the host and, hence, are likely to contribute to additional potential fractionation processes that need to be further studied. Another possible explanation for the light isotopic composition of coral tissue at depth is an extremely light food source for the coral, such as POM. However, the $\delta^{13} \mathrm{C}$ ratios of zooxanthellae and host did not change with depth below $30 \mathrm{~m}$ and no isotopically light carbon source was found, which weakens the likelihood that POM is driving the low light $\delta^{13} \mathrm{C}$ values of the tissue at depth.

\section{Morphology}

The relationship of the branching morphology of corals to heterotrophic versus autotrophic capacity has been debated by numerous authors (Wellington 1982, Fricke \& Hottinger 1983, Sebens et al. 1996, 1998). In the present study, Stylophora pistillata changed from a subspherical structure in well-lit environments to a flat, fan-like morphology in deep, dimly lit habitats (Fig. 3). This is consistent with previous data presented by Stambler \& Dubinsky (2005), demonstrating that a flat morphology (low surface to volume ratio) in lightlimited environments is the most efficient form for light trapping. We also found a significant decrease in branch diameter with depth (Fig. 4). Changes in branch diameter are interpreted as photoacclimation to maximize light harvesting (Fricke \& Hottinger 1983). Another depth-related trait is the decrease in the density of corallites, demonstrated in the present study and described by Fricke \& Schuhmacher (1983). Distribution and size of corallites may optimize heterotrophic nutrition and, on the other hand, may be optimal for photosynthesis (Anthony \& Fabricius 2000). Small and tightly packed corallites would increase the amount of surface area available for zooxanthellae, thereby maximizing photosynthetic potential. Crabbe \& Smith (2002) and Crabbe et al. (2004) have shown that polyps of colonies in low light environments may meet a greater proportion of their energetic requirements by heterotrophy; therefore, the corallites require better developed food-capturing mechanisms, such as a larger number and length of tentacles, proportional to increased corallite dimensions. Larger corallites would also decrease the chance of individual corallites becoming smothered by sediment deposits. However, $S$. pistillata corallites in the present study were smaller (autotrophic) and fewer (heterotrophic) with increasing depth. While this trait is effective in the optimization of light harvesting, it may not aid in improving prey-capture capabilities. Using isotopic data, Grottoli \& Wellington (1999) showed that mounding species from shallow sites showed no difference in reliance on heterotrophic input between congeners of differing polyp sizes. In addition, Palardy et al. (2005) showed that feeding rates increased with depth and were higher in coral species with mounding morphologies than in those with branching morphologies. They have also shown that feeding did not differ with polyp size within morphology. They suggested that coral feeding rates are facultative, may vary due to increased feeding effort and are not necessarily due to a change in colony morphology.

However, deep corals maintain a 10-fold slower growth rate than their shallow peers (Mass et al. 2007), and the energy available to invest in growth is distributed according to a totally different set of constraints. In addition, the dish-like form observed in many deepwater corals, incuding Stylophora pistillata in the present study, may also serve as a trap for marine snow and for predation on demersal zooplankton. McCloskey \& Muscatine (1984) showed that species that are highly phototrophic in shallow water rely more on heterotrophic inputs in deeper water. However, it is not known if the increased importance of heterotrophy to the coral diet is due to increased heterotrophic intake with depth, reduced light or both. Correlations between morphological traits to $\delta^{13} \mathrm{C}$ may be the result of the effect of depth on both factors; we suggest that this indicates dependence of the carbon composition on morphology, but not heterotrophic-dependent traits such as polyp size (Table 1).

\section{CONCLUSIONS}

We suggest that Stylophora pistillata depth-related morphological modifications optimize energy utilization from autotrophy, although isotopic data reflect heterotrophic behavior (lighter isotopes). S. pistillata morphology changes from a subspherical to a flat morphology as branches get thinner with depth (heterotrophic), and corallite size is reduced (autotrophic) 
while the spacing among corallites increases (autotrophic). Isotopic $\delta^{13} \mathrm{C}$ measurements from the host and zooxanthellae indicate internal cycling of carbon compounds between the host and its symbiotic algae.

We suspect that there is a steady-state flow of metabolites from the coral host tissue to the zooxanthellae and back. This process enables higher fractionation rates that can explain the relatively negative values of $\delta^{13} \mathrm{C}$ in the host tissue $(-23 \%)$ and the correlation between host and zooxanthellae values along the depth gradient. There was no increase in the difference between the $\delta^{13} \mathrm{C}$ values of coral tissue and $\delta^{13} \mathrm{C}$ values of zooxanthellae from $\geq 30 \mathrm{~m}$ and no evidence of lighter zooplankton were found which, together, weakens the possibility of dependence on other carbon sources and strengthens the recycling hypothesis.

Acknowledgements. This research was supported by the Israeli Science Foundation grant no. 981/05 and the Bundesministerium für Bildung und Forschung, Germany, grant no. gr1923-1300. We thank the anonymous reviewers for their insightful comments which significantly improved our manuscript.

\section{LITERATURE CITED}

Al-Moghrabi S, Goiran C, Allemand D, Speziale N, Jaubert J (1996) Inorganic carbon uptake for photosynthesis by the symbiotic coral-dinoflagellate association. II. Mechanisms for bicarbonate uptake. J Exp Mar Biol Ecol 199:227-248

Anthony KRN, Fabricius KE (2000) Shifting roles of heterotrophy and autotrophy in coral energetics under varying turbidity. J Exp Mar Biol Ecol 252:221-253

Bachar A, Achituv Y, Pasternak Z, Dubinsky Z (2007) Autotrophy versus heterotrophy: the origin of carbon determines its fate in a symbiotic sea anemone. J Exp Mar Biol Ecol 349:295-298

Brandt J (1883) Uber die morphologische und physiologische Bedeutung des Chlorophylls bei Tieren. Mitt Zool Stn Neapel 4:191-302

Bruno JF, Edmunds PJ (1997) Clonal variation for phenotypic plasticity in the coral Madracis mirabilis. Ecology 78:2177-2190

Crabbe MJC, Smith DJ (2002) Comparison of two reef sites in the Wakatobi Marine National Park (SE Sulawesi, Indonesia) using digital image analysis. Coral Reefs 21:242-244

Crabbe MJC, Karaviotis S, Smith DJ (2004) Monitoring growth of hard corals as performance indicators for coral reefs. J Biol Educ 38:113-117

Deniro MJ, Epstein S (1978) Influence of diet on distribution of carbon isotopes in animals. Geochim Cosmochim Acta 42:495-506

Deuser WG, Degens ET (1967) Carbon isotope fractionation in the system $\mathrm{CO}_{2}$ (gas) $-\mathrm{CO}_{2}$ (aqueous) $-\mathrm{HCO}_{3}{ }^{-}$(aqueous). Nature 215:1033-1035

Falkowski PG, Dubinsky Z, Muscatine L, McCloskey L (1993) Population control in symbiotic corals. Bioscience 43: 606-611

Fricke HH, Hottinger L (1983) Coral bioherms below the euphotic zone in the Red Sea. Mar Ecol Prog Ser 11: 113-117

Fricke HW, Schuhmacher H (1983) The depth limits of Red Sea stony corals: an ecophysiological problem (a deep diving survey by submersible). PSZN I: Mar Ecol 4:163-194

Furla P, Galgani I, Durand I, Allemand D (2000) Sources and mechanisms of inorganic carbon transport for coral calcification and photosynthesis. J Exp Biol 203:3445-3457

Goiran C, Al-Moghrabi S, Allemand D, Jaubert J (1996) Inorganic carbon uptake for photosynthesis by the symbiotic coral/dinoflagellate association. I. Photosynthetic performances of symbionts and dependence on sea water bicarbonate. J Exp Mar Biol Ecol 199:207-225

$>$ Goreau TF, Goreau NI (1959) The physiology of skeleton formation in corals. I. A method for measuring the rate of calcium deposition by corals under different conditions. Biol Bull 116:59-75

Grottoli AG, Wellington GM (1999) Effect of light and zooplankton on skeletal $\delta^{13} \mathrm{C}$ values in the eastern Pacific corals Pavona clavus and Pavona gigantea. Coral Reefs 18:29-41

> Grottoli AG, Rodrigues LJ, Palardy JE (2006) Heterotrophic plasticity and resilience in bleached corals. Nature 440: 1186-1189

> Maier C, Patzold J, Bak RPM (2003) The skeletal isotopic composition as an indicator of ecological and physiological plasticity in the coral genus Madracis. Coral Reefs 22: 370-380

> Mass T, Einbinder S, Brokovich E, Shashar N, Vago R, Erez J, Dubinsky Z (2007) Photoacclimation of Stylophora pistillata to light extremes: metabolism and calcification. Mar Ecol Prog Ser 334:93-102

McCloskey LR, Muscatine L (1984) Production and respiration in the Red Sea coral Stylophora pistillata as a function of depth. Proc R Soc Lond B Biol Sci 222:215-230

$>$ Mook WG, Bommerson JC, Staverman WH (1974) Carbon isotope fractionation between dissolved bicarbonate and gaseous carbon dioxide. Earth Planet Sci Lett 22:169-176

Muko S, Kawasaki K, Sakai K, Takasu F, Shigesada N (2000) Morphological plasticity in the coral Porites sillimaniani and its adaptive significance. Bull Mar Sci 66:225-239

Muscatine L, Porter JW, Kaplan IR (1989) Resource partitioning by reef corals as determined from stable isotope composition. $1 . \delta^{13} \mathrm{C}$ of zooxanthellae and animal tissue vs. depth. Mar Biol 100:185-193

> Muscatine L, Goiran C, Land L, Jaubert J, Cuif JP, Allemand $\mathrm{D}$ (2005) Stable isotopes $\left(\delta^{13} \mathrm{C}\right.$ and $\left.\delta^{15} \mathrm{~N}\right)$ of organic matrix from coral skeleton. Proc Natl Acad Sci USA 102: $1525-1530$

O'Leary MH (1988) Carbon isotopes in photosynthesis. Bioscience 38:328-336

Palardy JE, Grottoli AG, Matthews KA (2005) Effects of upwelling, depth, morphology and polyp size on feeding in three species of Panamanian corals. Mar Ecol Prog Ser 300:79-89

Porter JW (1976) Autotrophy, heterotrophy, and resource partitioning in Caribbean reef-building corals. Am Nat 110:731-742

Schneider K, Erez J (2006) The effect of carbonate chemistry on calcification and photosynthesis in the hermatypic coral Acropora eurystoma. Limnol Oceanogr 51: 1284-1293

> Sebens KP, Vandersall KS, Savina LA, Graham KR (1996) Zooplankton capture by two scleractinian corals, Madracis mirabilis and Montastrea cavernosa, in a field enclosure. Mar Biol 127:303-317

Sebens KP, Grace SP, Helmuth B, Maney EJ, Miles JS (1998) 
Water flow and prey capture by three scleractinian corals, Madracis mirabilis, Montastrea cavernosa and Porites porites, in a field enclosure. Mar Biol 131:347-360

Stambler N, Dubinsky Z (2005) Corals as light collectors: an integrating sphere approach. Coral Reefs 24:1-9

Swart PK, Saied A, Lamb K (2005) Temporal and spatial variation in the $\delta^{15} \mathrm{~N}$ and $\delta^{13} \mathrm{C}$ of coral tissue and zooxanthellae in Montastraea faveolata collected from the Florida reef

Editorial responsibility: Otto Kinne,

Oldendorf/Luhe, Germany tract. Limnol Oceanogr 50:1049-1058

Vermeij MJA, Bak RPM (2003) Species-specific population structure of closely related coral morphospecies along a depth gradient (5-60 m) over a Caribbean reef slope. Bull Mar Sci 73:725-744

Wellington GM (1982) An experimental analysis of the effects of light and zooplankton on coral zonation. Oecologia 52:311-320

Submitted: July 29, 2008; Accepted: December 22, 2008 Proofs received from author(s): April 4, 2009 